\title{
HISTOMORPHOMETRIC ESTIMATION OF AGE FROM BONE SAMPLES OF NIGERIANS
}

\author{
*C.D. Orupabo', L.E. Oghenemavwe', T.E. Diamond ${ }^{2}$ \\ 1 - DEPARTMENT OF HUMAN ANATOMY, UNIVERSITY OF PORT HARCOURT, \\ PORT HARCOURT, NIGERIA \\ 2 - DEPARTMENT OF ORTHOPAEDICS AND SURGERY, UNIVERSITY OF PORT HARCOURT TEACHING \\ HOSPITAL, PORT HARCOURT, NIGERIA
}

Background. Age estimation is crucial in creating the biological profile of unknown skeletal remains and recently there is emphasis on the need to develop population specific forensic baseline data for easy identification of these remains.

Objective. The aim of this study is to estimate age from the histomorphometric features of the bones of Nigerians.

Methods. Fragments of non-pathologic bone samples were collected during orthopaedic procedures. Ground sections were prepared using Modified Frost's manual method of bone preparation to determine the following histologic parameters; haversian canal diameter (HCD), primary and secondary osteons, number of osteon fragments and non-haversian canal as well as haversian canal area (HCA). 29 subjects aged 35 to 85 years old were used for the study. Bone fragments included samples from the femur, tibia, humerus, and the vertebrae. Data obtained were subjected to descriptive statistics, Pearson's correlation, bivariate regression equation, Student t-test and analysis of variance (ANOVA).

Results. The mean age for our population was 58.86 years old. ANOVA showed significant variation in the average $H C D$ for the various regions: humerus $=8.45 \pm 2.48$, femur $=7.09 \pm 4.06$, tibia $=8.70 \pm 2.52$ and vertebrae $=3.69 \pm 0.73$. There was a strong inverse relationship between age and primary osteons. The total number of osteon fragments increased with age while total number of primary osteons and average HCD decreased with age. The HCA, though statistically insignificant, also decreased with age.

Conclusion. Our findings show that three histomorphometric parameters showed significant correlation with age: osteon fragments (OS-f), primary osteons (OS-p) and HCD. The histomorphometric parameters were therefore relevant in age estimation.

KEYWORDS: age estimation; histomorphometric parameters; Nigerians; forensics.

\section{Introduction}

Age estimation from the macrostructure of bones is an aged-long anatomical practice, which has progressed into studying the micro structural features. Hence, it is an important tool in physical anthropology as well as in forensic medicine in the identification of skeletal remains. Once age and sex are estimated, the identity of the skeletal remains is established for about $80 \%[1,2,3]$.

There are few methods used by forensic scientists whenever the issue of age assessment arises and as such several approaches have been developed. These methods include the use of dental eruptions periods $[4,5,6]$, time of epiphyseal fusion of some bones and micro*Corresponding author: Clinton David Orupabo, Department of Human Anatomy, Faculty of Basic Medical Sciences, College of Health Sciences, University of Port Harcourt, East-West road, PMB 5323, Choba, Rivers state, Nigeria.

E-mail: clinton.orupabo@ust.edu.ng scopic or histological features of cortical bones $[7,8,9]$, morphology of the pubic symphysis and auricular surface of the Ilium $[10,11,12]$ the skull and length of long bones $[13,6,7]$, sternal ends of the $3 r d, 4$ th and 5 th ribs $[14,15]$. These foremost macrostructural approaches have lots of limitations as only some bones like the pelvic bone and some long bones give reliable results [16]. These approaches also require the researcher to employ wide age ranges during age assessment of the subjects that would introduce major difficulties in age estimation of specimen $[16,17]$.

In order to overcome the limitations posed by the macroscopic methods, in 1965 Kerley developed the quantification of histological features of cortical bone for age estimation [18, $19,20,21]$. Since bone growth, development and changes occurs with age, it was presumed that the study of the histological features of 
bones could be important in the estimation of age for human populations [22, 23, 21, 24, 25]. According to De Boer and Maat (2003) [26] and Thomas et al. (2000) [27], the histological findings must be combined with gross anatomical and radiological findings to obtain a conclusive diagnosis or to shorten a list of differential diagnosis.

Singh and Gunberg (1970) [22] and Wolf et al. (2017) [28] demonstrated the use of fragmentary remains of bone to determine age from histology. Some studies from different populations have used the quantification of osteon in age estimation [29, 30,31]. A common finding of these studies is that the number of osteon and diameter of the Haversian canal changes with age $[2,18,32,33]$. Steyn et al. (2004) [33] also observed that age estimation was easy in children compared to adults due to bone remodeling and degeneration, and became more difficult in older ages. Currently, it has been established that there is need to generate forensic data for age, sex and stature estimation for different populations, as anatomical landmarks are influenced by diet, disease, genes, sex and racial peculiarities [16, 34]. This study therefore seeks to generate baseline data for age estimation from bone histology among Nigerians.

\section{Methods}

This is a descriptive and correlational study involving life subjects. Fragments of bone samples were collected during orthopedic procedures with data on the age, sex, tribe and type of pathology or clinical diagnosis of the subjects. Bone samples collection and tissue preparation took a period of about six months. Samples were collected from the Orthopedic departments of The University of Port Harcourt Teaching Hospital (UPTH) and Rivers State University Teaching Hospital (RSUTH), as well as Rehoboth Specialist Hospital Port Harcourt and Twin Towers Specialist Hospital Port Harcourt. Ethical Approval

Ethical approval was sought from the University of Port Harcourt Research Ethics committee and was granted. A consent form was issued to each patient and an informed consent was obtained after thorough guidance and counselling of the patient.

Sample was drawn from orthopedic patients with no prior or background metabolic disease. Bone fragments were collected from amputations and other orthopedic procedures where bone fragments could be harvested. A total number of 29 subjects with samples from 12 females and 17 males aged 35 to 85 years old were used for study. Bone fragments included samples from the femur, tibia, humerus, and the vertebrae. The samples included healthy and strong bone fragments without any periosteal disruption. Diseased bone fragments shattered during grinding were excluded during processing. The sampling technique involved a convenience sampling method. The bone fragments were collected and ground sections were prepared using the Modified Frost's manual method of bone preparation $[35,36,16]$. Bone fragments were collected in properly labeled plain containers during operations and immersed in water for about 1 week to enable soft tissue removal. Some of the soft tissues were manually removed gently to prevent distortion of the periosteal layer of the bones. The samples were subsequently fixed in $10 \%$ formalin for one more week. The volume of fixative is 10-20x the size of the bone to allow adequate penetration of fixative.

With the help of a hacksaw, thin cross sections of bone fragments were made. A glass slab coated with Vaseline was prepared. A p220 sand paper was placed on the slab. The application of Vaseline helps prevent moisture and allows close and smooth adherence of the sand paper to the glass plate. This would allow proper and concurrent thinning of all edges of the bones during subsequent grinding. The rectangular glass slab measured $16 \mathrm{~cm} \times 12 \mathrm{~cm}$ and the sand paper was cut to a little more than the size of the glass slab. This would prevent water from escaping into the underside of the paper. A drop of water was dropped on the sand paper and the Modified Frost's manual method of bone preparation was adopted. This method was implemented owing to the distortion of micro architecture of tissues with decalcification before routine histology. Gentle grinding of bone sections was done by moving the pulp of the finger on the bone over the sand paper in a cyclical fashion. This would enable thinning uniformity of the bone edges. This would also prevent easy cracking and breaking of sections as they get thinner. Water was added continually during grinding progresses to enable lubrication and reduce of friction. Physical observation of sections for thinness was done by means of a tweezer and a fine brush. With the help of frost's holder, very thin sections were held for grinding until required degree of thinness was attained. During the grinding process, utmost care was taken to avoid scratching away of the 
periosteum. Hence bone sections were turned from one surface to another to allow for evenness of thinning. Grinding was done until bone sections appeared opaque, and then transparent and even easily bendable using the fine brush. Ready specimens were placed in a beaker containing distil water and a little drop of detergent in order to properly rinse out dirt and stains from the specimens. Washing was performed by the tweezer and the fine brush. Rinsed specimens were then placed on a filter paper in a Petri dish to allow for drying of the specimen. The filter paper was gently roughened before use. This allowed for ease of pick of the section with the fine brush after drying. Glass slides were then cleaned with absolute alcohol and then placed on a glass slab having a dark background. This was achieved by placing a black sheet of paper or polythene behind the glass slab. A drop of DPX mountant was placed on the glass slides. The dried specimen was placed on a top of the mountant. Another drop of the mountant was immediately dropped on the specimen to allow proper immersion of the specimen. Glass cover slips washed in xylene were placed over the specimen. The mountant was seen to spread evenly from under the cover slip. Air bubbles trapped under the cover slip in some specimens were removed by gentle pressure of the cover slip with the tweezer. Ready slides were allowed to dry and correctly labelled. They were kept to dry in a horizontal position for about 24 hours before loading into glass boxes. Ready slides were mounted under a photomicroscope for viewing and analysis. The Leica ICC 50E photomicroscope was used to view and demonstrate the histological features. Photomicrographs of fields adjudged by two researchers to have more osteon density were taken. This was done after thorough review and examination of the entire field under study.

\section{Results}

Table 1 shows the various histomorphometric parameters studied. Their mean distribution as well as the minimum and maximum values for each parameter is also presented. The average age distribution for sample population is shown as well.

Table 2 shows the mean age, average HCD, standard deviation and variance of the Haversian canal diameter of various bones studied. The average HCD for the various regions is as follows: humerus $=8.45 \pm 2.48$, femur $=7.09 \pm 4.06$, tibia $=8.70 \pm 2.52$ and vertebrae $=3.69 \pm 0.73$.

Table 3 demonstrates the use of ANOVA in determining the degree of variation in the HCD of the various bones studied. The $F$ value is greater than the $\mathrm{F}$ critical for an alpha level of 0.05 . This proves that there is a significant variation between the mean of the various Haversian canal diameter of the bones studied. The $P$ value obtained here $(P=0.00)$ is also less than the alpha level chosen (0.05). This evidences that the variation in the Haversian canal diameter of the various bones is very significant.

Table 4 presents the regression equation derived for age estimation using the various

Table 1. Descriptive Statistics of Age and bone histomorphometric variables

\begin{tabular}{|l|c|c|c|c|c|c|}
\hline Parameters & Mean & $\begin{array}{c}\text { Standard error } \\
\text { of mean }\end{array}$ & $\begin{array}{c}\text { Standard } \\
\text { deviation }\end{array}$ & Variation & $\begin{array}{c}\text { Minimum } \\
\text { variation }\end{array}$ & $\begin{array}{c}\text { Maximum } \\
\text { variation }\end{array}$ \\
\hline Age & 58.86 & 3.52 & 16.50 & 272.12 & 35.00 & 85.00 \\
\hline OS-p & 2.14 & 0.58 & 2.71 & 7.36 & 0.00 & 11.00 \\
\hline OS-S & 2.45 & 0.83 & 3.89 & 15.12 & 0.00 & 12.00 \\
\hline OS-f & 7.00 & 1.29 & 6.04 & 36.48 & 0.00 & 22.00 \\
\hline N-hc & 2.32 & 0.47 & 2.19 & 4.80 & 0.00 & 7.00 \\
\hline Area HC & 54.13 & 4.70 & 68.71 & 3446.74 & 3.53 & 534.35 \\
\hline HCD & 7.53 & 0.28 & 3.51 & 12.31 & 2.19 & 26.08 \\
\hline
\end{tabular}

Notes: OS- $p=$ primary osteon, OS-s=secondary osteon, OS-f=osteon fragment, $\mathrm{N}$-hc=Non haversian canal, HC=Haversian canal, $H C D=$ Haversian canal diameter.

Table 2. The Average Haversian canal diameter for the different bones

\begin{tabular}{|l|c|c|c|c|c|}
\hline \multicolumn{1}{|c|}{ Groups } & Mean age (years) & Counts & Sum & Average (microns) & Standard deviation \\
\hline Humerus & 67 & 31 & 262.06 & 8.453484 & 2.48 \\
\hline Femur & 60.71 & 41 & 356.51 & 7.090278 & 4.06 \\
\hline Tibia & 55.33 & 72 & 510.50 & 8.695366 & 2.52 \\
\hline Vertebrae & 51 & 11 & 40.60 & 3.690909 & 0.73 \\
\hline
\end{tabular}


Table 3. Test of Variation in HCD using ANOVA

\begin{tabular}{|l|c|c|c|c|c|c|}
\hline $\begin{array}{c}\text { Source } \\
\text { of Variation }\end{array}$ & SS & df & MS & F value & $\begin{array}{c}\text { P-value } \\
(P<0.05)\end{array}$ & F critical \\
\hline Between groups & 258.1242 & 3 & 86.0414 & 7.905552 & $0.00 * *$ & 2.664504 \\
\hline Within groups & 1643.434 & 151 & 10.88367 & & & \\
\hline Total & 1901.558 & 154 & & & & \\
\hline
\end{tabular}

Notes: HCD - Haversian canal diameter, ** - very significant.

Table 4. Correlation, coefficient of determination and regression equation for age versus bone histomorphometric variables

\begin{tabular}{|l|c|c|c|c|c|}
\hline Parameters & $\begin{array}{c}\text { Correlation } \\
\text { coefficient } \AA\end{array}$ & $\begin{array}{c}\text { Coefficient } \\
\text { of determination }\end{array}$ & t value & P value & $\begin{array}{c}\text { Regression } \\
\text { equation }\end{array}$ \\
\hline OS-p & 0.37 & 0.14 & 1.78 & 0.09 & $\mathrm{y}=-2.29 \mathrm{x}+63.75$ \\
\hline OS-s & 0.17 & 0.03 & 0.77 & 0.45 & $\mathrm{y}=0.71 \mathrm{x}+60.59$ \\
\hline OS-f & 0.30 & 0.09 & 1.41 & 0.17 & $\mathrm{y}=0.812 \mathrm{x}+53.18$ \\
\hline N-hc & 0.10 & 0.01 & 0.45 & 0.66 & $\mathrm{y}=0.8926 \mathrm{x}+50.79$ \\
\hline Area HC & 0.24 & 0.056 & 1.10 & 0.28 & $\mathrm{Y}=-0.0568 \mathrm{x}+58.896$ \\
\hline HCD & 0.26 & 0.069 & 1.21 & 0.24 & $\mathrm{Y}=-1.0554 \mathrm{x}+63.768$ \\
\hline
\end{tabular}

Notes: OS- $p=$ primary osteon, OS-s=secondary osteon, OS-f=osteon fragment, $N$-hc=Non Haversian canal, $H C=H a v e r s i a n$ canal, $H C D=$ Haversian canal diameter, $Y=$ Predicted Age, $x=$ Parameter under consideration.

histomorphometric parameters. It also shows the correlation coefficient and coefficient of determination as well as the $t$ and $p$ values of the variables.

\section{Discussion}

Our study considered the correlation between age and histological parameters such as primary osteons (OS-p), secondary osteons (OS-s), and osteon fragments (OS-f), nonhaversian canals ( $n-H C)$, Haversian canal area (HCA) and Haversian canal diameter (HCD). The mean age for our total population was 58.86 years old (Table 1). The average HCD also appeared to vary with the region of bone chosen as we obtained 8.45 microns for humerus, 8.70 microns for tibia, 7.09 microns for femur and 3.69 microns for the vertebra (Table 2).

It is also possible that bone density contributed to the size of Haversian canal as demonstrated with the vertebrae. Although the mean ages for tibia and vertebrae are similar, the variation in HCD is large, and more so when compared with the femur and humerus. ANOVA test also shows that there is a significant variation between the mean of the various Haversian canal diameter of the bones studied ( $F$ value $>$ F crit. at alpha level 0.05) (Table 3). The P-value $(P=0)$ at alpha level 0.05 is also less than the alpha level (Table 3). This proves that variation in the HCD of the various bones is significant $(P<0.05)$. These differences seen with different regions could be due to varying bone activity and bone density. It is supposed therefore that age and aging could not be the major reason for these regional differences. The vertebra is not exposed to too much stress and activity as compared to the long bones, especially the tibia, which is a major weight bearing bone. Whether these findings could differ with occupation and especially in gymnasts is yet to be ascertained. According to Keough (2007) [16], the average Haversian canal diameter (HCD) ranges at 30-70 microns. This is quite at variance with our values as our study obtained a range of approximately 2.2-26.1 microns. The reasons also could be the type of sample used. Keough used samples from femoral mid-shaft from a predominantly black South African population and being within a similar mean age to ours. Also, Singh and Gunberg (1970) [22] in a study on bone fragments of male American population of similar age group discovered that HCD varies with region of bone chosen for the study and obtained average HCD of 63.44 microns for the mandible fragments, 43.24 microns for the femur and 45.54 microns for the tibia. Both previous studies used skeletal collections from cadavers of a white and some black population whereas our study used skeletal remains of live humans from Nigerian population. Whether the wide variation is related to the tribe or the type of sample used is yet to be determined. However, it is obvious 
that Nigerians may have far lower average HCD than other populations studied. Our study discovered that HCD decreases as age increases (Fig. 1).

This agrees with Singh and Gunberg, (1970) [22] who studied American population and reported that HCD decreases as age increases. They also established strong correlation with age. They proved that between age of 40-45 years old the HCD could range between 85-92 microns, and could fall to a range of 51-58 microns at age of 70-80 years old. Though we obtained smaller HCD for the Nigerian population, our sample was collected largely from an older age group of between 55-85 years old, hence the reason to have obtained small HCD for age. Whether ethnicity, socioeconomic status, diet or undiagnosed disease may have an impact, this outcome is yet to be ascertained as it is not within the scope of this study. Landeros and Frost (1964) [37] also proved that closure of the Haversian canal continues as age increases, hence consenting to a reduced diameter with age. However, Keough (2007) [16] reported a slight positive correlation $(r=$ 0.1377 ) with age and supposed males showed highest correlation with age $(r=0.9964)$. He also noted that this parameter could not be a strong estimator of age. Likewise Sobol et al, (2014) [9] established that HCD increased with age and assumed it was one of the best predictors of age. But Barer and Josey, (1967) [38] reported little or no age-related changes in the size of the Haversian canal. As age increases, the HC area decreases (Fig. 2).

The coefficient of determination $\left(r^{2}=0.056\right)$ was quite small (Table 4 ), showing that only $5 \%$ variation in age of the subjects can be explained by the total Haversian canal area of the samples. Hence though there is a correlation with age, the coefficient of determination shows that this parameter may be weak in age estimation. The HCD thus has a stronger correlation with age compared to the Haversian canal area. The HCD is therefore a better estimator of age compared to the Haversian canal area.

Fig. 3 shows a strong inverse relationship between age and primary osteons (OS-p). The younger age groups appear to have more number of primary osteons.

This is in consent with Enlow (1963) [39] and Keough, (2007) [16] who have established that primary osteons is more in the younger age group. Non Haversian canal shows no correlation with age ( $r=0.10)$ (Fig. 4).
This finding also contradicts the reports of many researchers who have proved that N-hc decreases with age $[32,30,16]$. For instance, Ericksen (1991) [32] established that N-hc decreased with age for both sexes. Also, Keough (2007) [16] noted that after 55 years of age, the presence of non Haversian canals ceased almost completely. It is also important to note that Tersigni's (2005) report agrees with our data where he wrote that N-hc showed no significant variation with age [40].

Both primary osteons and non-Haversian canals make up the total number of unmodeled bone. Bone remodeling occurs in response to stressors and graded amount of activity, and

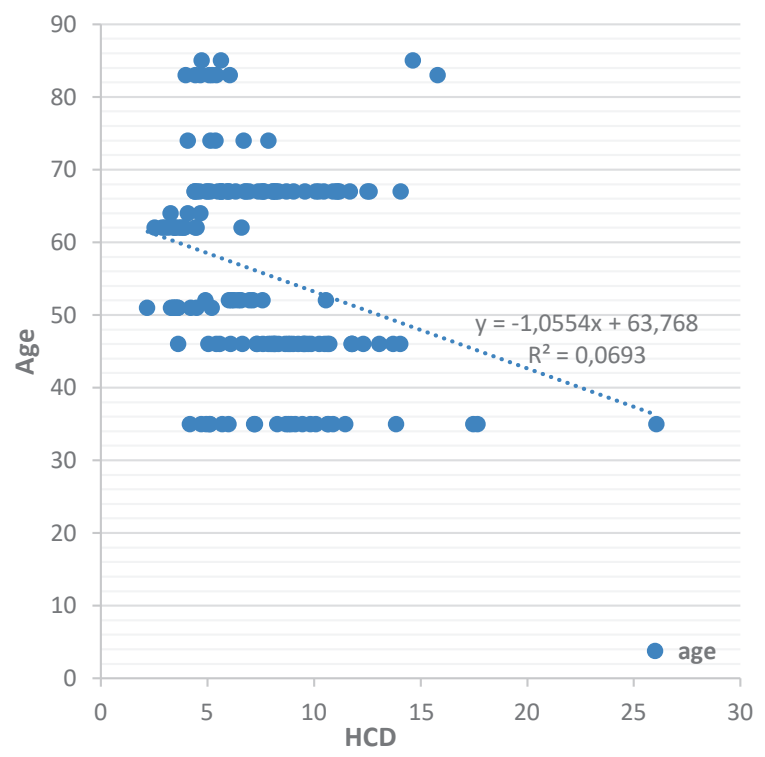

Fig. 1. Scatter plot of Age versus HCD.

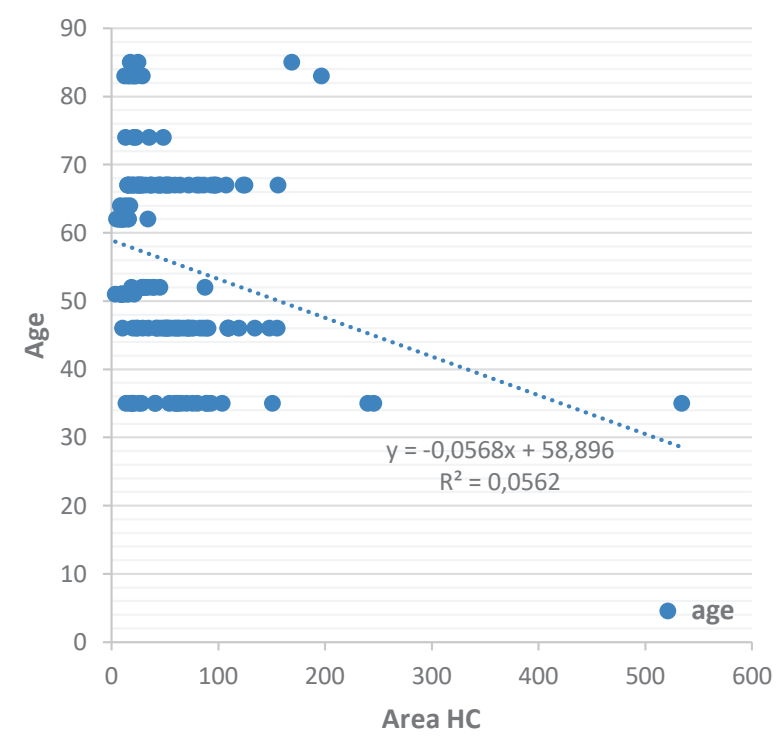

Fig. 2. Scatter plot of Age versus Area-HC. 


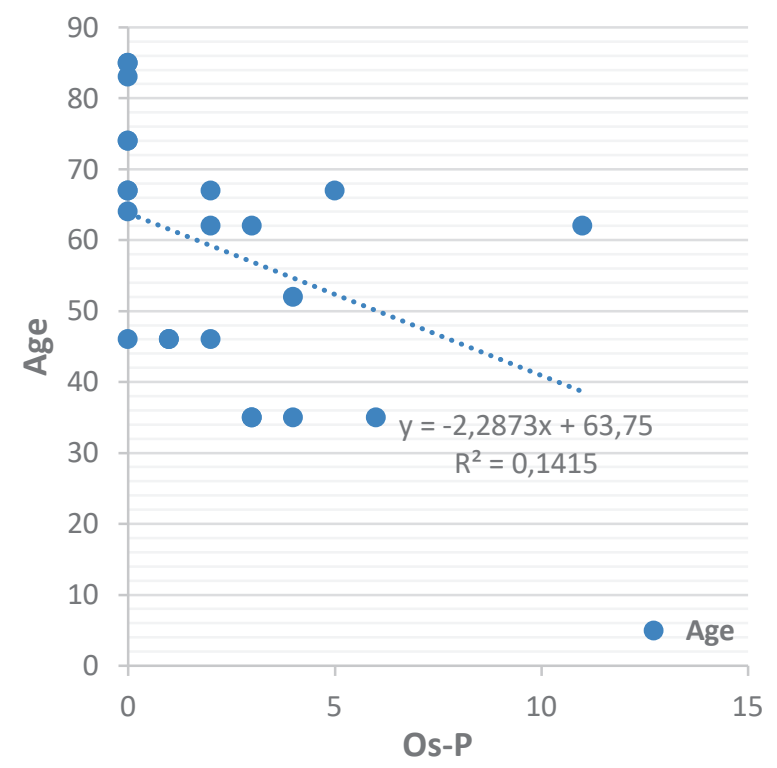

Fig. 3. Scatter plot of Age versus Os-p.

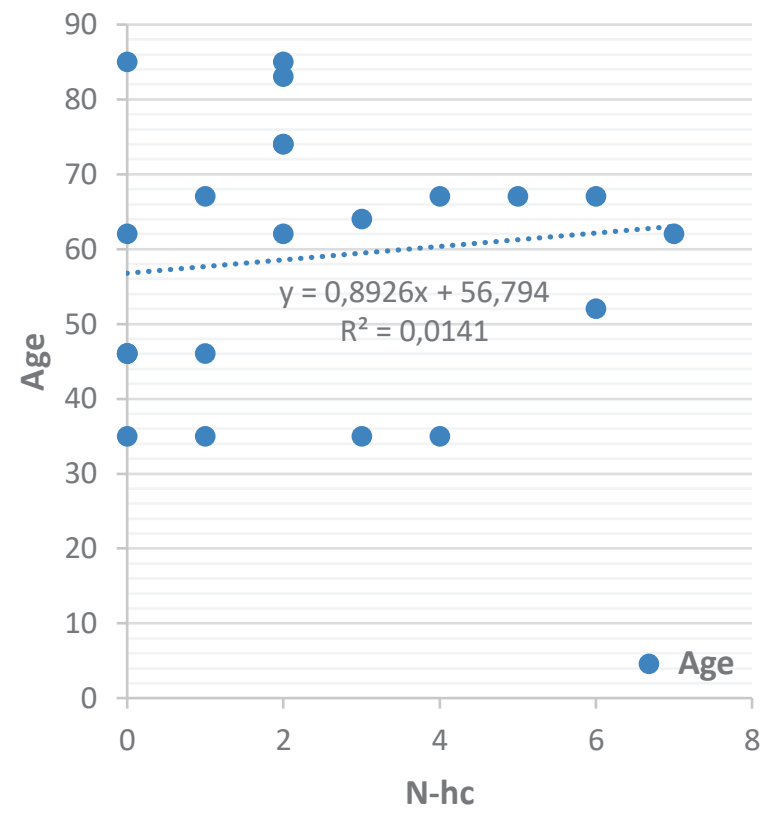

Fig. 4. Scatter plot of Age versus N-hc.

this therefore increases with age. Therefore, finding more primary osteons in the younger age group is justifiable as proved in our research findings. Ingraham (2004) [30] confirmed our findings when he reported that percentage of unremodeled bone is higher in the younger age with $53.4 \%$ for 18 years of age and $2.2 \%$ for 69 years of age.

Fig. 6 reveals a photomicrograph taking under a magnification of $\times 100$ for two males at ages of 67 and 35 years old. The features seen were predominantly secondary osteons for the older age and unremodeled bone for the younger individual. These findings were expected as bone remodeling increases with age. These findings however are not consistent with all ages in our study; hence the reasons could be for variable underlying factors like sex, tribe, genetics, undiagnosed metabolic disease, exposure to various levels of stress, as well as variation in graded level of activity for different individuals. Osteon fragment in our study has a weak positive correlation with age $(r=0.30)$ and statistically insignificant ( $p>0.05$ ) (Table 4) (Fig. 5).

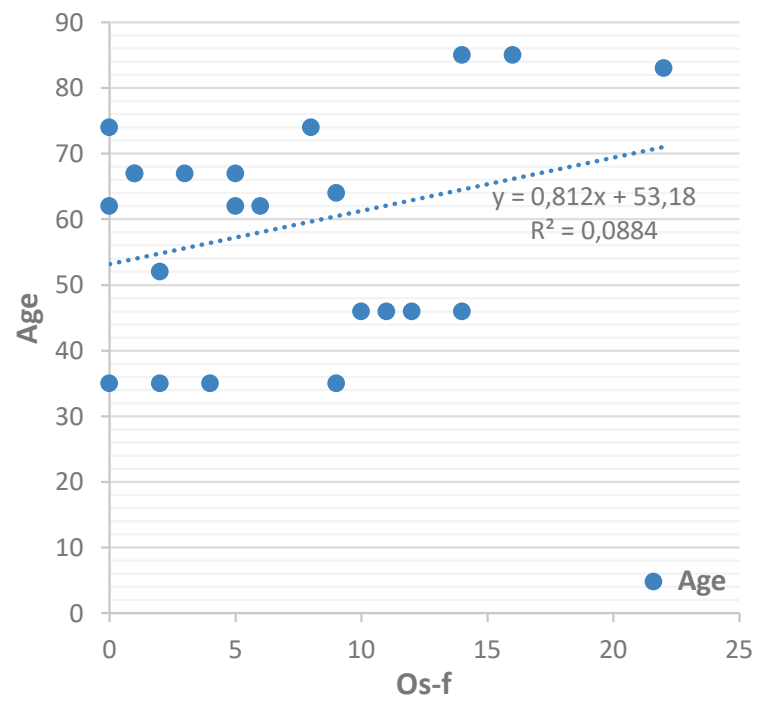

Fig. 5. Scatter plot of Age versus Os-f.

Keough (2007) [16] documented that osteon fragments showed significant correlation with age $(r=0.55)$. Kerley's (1965) [18] novel research on bone histology proved our findings and stated that osteon fragments were best predictors of age using the fibula. This has been proved by our research and by several authors using various other segments of bones. Keough (2007) [16] also established that four of the histomorphometric parameters studied showed significant correlation with age: total osteon count $(r=0.53)$, \% unremodeled bone $(r=0.53)$, total $N-h c(r=0.55)$ and \% osteon fragment $(r=0.55)$. In his study, total osteon count and percentage osteon fragments increased with age while percentage of unremodeled bone and non Haversian canal decreased with age. Our findings proved that three histomorphometric parameters showed positive correlation with age: osteon fragments (OS-f), primary osteons (OS-p) and the Haversian canal diameter (HCD). 
In our study, the total number of osteon fragments increased with age while total number of primary osteons and average Haversian canal diameter decreased with age. The area of Haversian canal, though statistically insignificant, also decreased with age. The number of non-Haversian canal also increased with age but was statistically not significant as well. We can therefore infer that the Haversian canal area, the non-Haversian canals and the secondary osteons show no significant variation with age. Purves et al. (2011) [41], stated in their study that osteon number was very reliable in age estimation but influenced by nutrition, disease, population and sex. Whether these factors had a great impact on our findings is yet to be ascertained as it is not within the scope of this study. Our samples were obtained from clinically healthy subjects. However about $69 \%$ of Nigerians live far below the poverty level according to the 2019 global multidimensional poverty index report by UNDP/OPHI [42], it is not without doubt that nutrition could be a factor. Steyn (2004) [33] in her research on adult age estimation reported that age estimation was difficult in adults and more difficult in older ages. Hence, she advised use of multifactorial approach. This would therefore combine both histological and macroscopic findings, especially where both can be readily available. In the absence of whole skeletal collections, the use of fragmentary remains becomes the main stay. However, in order to make this more robust and accurate, any possible finding on culture, environment and data on DNA can make a whole lot of difference.

Study limitations

The availability and access to bone samples is one foremost limitation to this study. Skeletal remains and bone samples are handled with much pessimism in our culture for fear of ritualists; hence processes for obtaining samples were quite laborious and challenging. Another major limitation to our study is the inability to use cadavers for the research. Our use of cadavers may have allowed access to lots of samples but nonetheless most of our cadavers are not profiled unlike what is obtainable in other countries.

\section{Conclusions}

The histomorphometric parameters are therefore relevant in age estimation and sex identification. Most forensic case identification without choice needs skeletal remains in order to investigate their victim. Forensic investigation of Nigerians would therefore need the analysis of the primary osteons, the osteon fragments and the Haversian canal diameter as proved in our research. Thus, since histomorphometric variations with population are influenced by environment, diet and genetics, age and aging of an individual is therefore not a major factor in influencing the histological changes seen, especially for individuals who are within a similar age bracket. Hence any forensic case investigation should, if possible and if the data are available, consider the multifactorial approach.

\section{Acknowledgements}

Most sincere thanks to my supervisor and others who rendered one support or the other. Special thanks to the Acting Vice Chancellor of Rivers State University whose financial support aided my travel to South Africa in order to study the technicalities that eased the execution of this work. The authors also thank Twin Towers and Rehoboth Specialist Hospitals as well as the University of Port Harcourt Teaching Hospital where our samples were obtained.

\section{Conflict of Interest}

The authors declare no conflict of interest. Funding

This research received no external funding.

\section{Author's Contributions}

Loveday Oghenemavwe, Clinton David Orupabo - conceptualization, methodology, formal analysis, writing - original draft, writing - reviewing and editing; Loveday Oghenemavwe, Clinton David Orupabo, Tamunokuro Diamond data curation, investigation. 


\title{
ОЦІНКА ВІКУ ЗА ГІСТОМОРФОМЕТРИЧНИМИ ОСОБЛИВОСТЯМИ КІСТОК НІГЕРІЙЦІВ
}

\author{
C.D. Orupabo' ${ }^{1}$ L.E. Oghenemavwe' ${ }^{1}$, T.E. Diamond ${ }^{2}$ \\ 1 - DEPARTMENT OF HUMAN ANATOMY, UNIVERSITY OF PORT HARCOURT, PORT HARCOURT, NIGERIA \\ 2 - DEPARTMENT OF ORTHOPAEDICS \& SURGERY, UNIVERSITY OF PORT HARCOURT TEACHING HOSPITAL, PORT \\ HARCOURT, NIGERIA
}

Вступ. Оцінка віку має вирішальне значення для створення біологічного профілю невідомих скелетних останків, і останнім часом робиться наголос на необхідності розробки специфічних для певної когорти населення судово-медичних даних для легкої ідентифікації чих останків.

Мета. Метою цього дослідження була оцінка віку за гістоморфометричними особливостями кісток нігерійців.

Методи. Фрагменти непатологічних зразків кісток збиралися під час ортопедичних процедур. Зрізи були підготовлені за допомогою модифікованого ручного методу підготовки кісток для визначення наступних гістологічних параметрів: діаметр каналу Гаверса (HCD), первинний та вторинний остеони, кількість фрагментів остеону та негаверсових каналів, а також площа каналу Гаверса (HCА). Для дослідження було використано 29 досліджуваниху віці від 35 до 85 років. Осколки кісток включали зразки стегнової, гомілкової, плечової кісток та хребців. Отримані дані піддавали описовій статистиці, корелячії Пірсона, двовимірному рівнянню регресії, t-критерію Стьюдента та дисперсійному аналізу (ANOVA).

Результати. Середній вік для нашого населення становив 58,86 років. ANOVA демонструє значні коливання середнього показника HCD для різних регіонів: плечова кістка $=8,45 \pm 2,48$, стегнова кістка $=7,09 \pm 4,06$, гомілка $=8,70 \pm 2,52$ та хребці $=3,69 \pm 0,73$. Між віком та первинними остеонами існує сильний зворотний зв'язок. Загальна кількість фрагментів остеону зростала з віком, тоді як загальна кількість первинних остеонів та середнє значення HCD зменшувались із віком. НСА, хоча і статистично незначний, також зменшувався з віком.

Висновок. Отримані нами результати показують, що три гістоморфометричні параметри продемонстрували значну кореляцію з віком: фрагменти остеонів (OS-f), первинні остеони (OS-p) та HCD. Тому гістоморфометричні параметри є важливими для оцінки віку.

КЛЮчОВІ СЛОВА: оцінка віку; гістоморфометричні параметри; нігерійці; криміналістика.

Information about the authors

Clinton David Orupabo, Lecturer 1, Department of Human Anatomy, University of Port Harcourt, Port Harcourt, Nigeria

ORCID 000-0002-4784-4273, e-mail: clinton.orupabo@ust.edu.ng

Loveday Ese Oghenemavwe, Supervisor/Reviewer/Senior Lecturer, Department of Human Anatomy, University of Port Harcourt, Port Harcourt, Nigeria

ORCID 0000-0002-3575-9987, e-mail: loveday.oghenemavwe@uniport.edu.ng

Tamunokuro Ezekeil Diamond, Assistant Researcher/Consultant, Department of Orthopaedics and Surgery, University of Port Harcourt Teaching Hospital, Port Harcourt, Nigeria

ORCID 0000-0002-8423-0377, e-mail: teddymond@gmail.com

\section{References}

1. Lynnerup N, Thomsen JL, Frohlich B. Intra-and inter-observer variation in histological criteria used in age at death determination based on femoral cortical bone. Forensic Sci Int. 1998 Feb 16;91(3): 219-30. 00197-7

DOI: https://doi.org/10.1016/S0379-0738(97)

2. Maat GJ, Maes A, Aarents MJ, Nagelkerke NJ. Histological age prediction from the femur in a contemporary Dutch sample. The decrease of nonremodeled bone in the anterior cortex.J Forensic Sci. 2006 Mar;51(2):230-7.

DOI: https://doi.org/10.1111/j.1556-4029. 2006.00062.x

3. Kosior W. Age and notions related to it in Greek non-legal sources-the contribution to the research of Roman law. Roczniki Administracji i Prawa. 2016;16:85-96. 
4. Smith HB. Standards of human tooth formation and dental age assessment. In: Kelley MA, Larson CS (eds). Advances in Dental Anthropology. New York: WileLiss; 1991 . p. 143-68.

5. Lundy JK. Forensic anthropology: What bones can tell us. Lab Med. 1998;29(7):423-27

DOI: https://doi.org/10.1093/labmed/29.7.423

6. Loth SR and İsçan MY. Morphological age estimation. In: Siegal J, Saukko P, Knupfer G (eds). Encyclopedia of Forensic Sci. Academic Press; 2012 Dec 28. p.242-52.

DOI: https://doi.org/10.1006/rwfs.2000.0755

7. Cunningham C, Scheuer L, Black S. Developmental juvenile osteology. Academic press; 2016 Jul 26.

DOI: https://doi.org/10.1016/B978-0126240009/50004-6

8. Scheuer L. Application of osteology to forensic medicine. Clin Anat. 2002 Jun;15(4):297-312.

DOI: https://doi.org/10.1002/ca.10028

9. Sobol J, Ptaszyńska-Sarosiek I, Charuta A, Oklota-Horba M, Żaba C, Niemcunowicz-Janica A. Estimation of age at death: examination of variation in cortical bone histology within the human clavicle. Folia Morphol (Warsz). 2015;74(3):378-88.

DOI: https://doi.org/10.5603/FM.2015.0021

10. Krogman WM, Iscan MY. The Human Skeleton in Forensic Medicine. 2nd Edition, Charles C. Thomas, Springfield. 1986

DOI: https://doi.org/10.1002/ajpa.1330740117

11. Buckberry JL, Chamberlain AT. Age estimation from the auricular surface of the ilium: a revised method. American Journal of Physical Anthropology: The Official Publication of the American Association of Physical Anthropologists. 2002 Nov;119(3):231-9.

DOI: https://doi.org/10.1002/ajpa.10130

12. Igarashi $Y$, Uesu K, Wakebe T, Kanazawa E. New method for estimation of adult skeletal age at death from the morphology of the auricular surface of the ilium. American Journal of Physical Anthropology: The Official Publication of the American Association of Physical Anthropologists. 2005 Oct;128(2):324-39.

DOI: https://doi.org/10.1002/ajpa.20081

13. Redfield A. A new aid to aging immature skeletons: development of the occipital bone. American Journal of Physical Anthropology. 1970 Sep;33(2): 207-20.

DOI: https://doi.org/10.1002/ajpa.1330330206

14. Stout SD, Dietze WH, Işcan MY, Loth SR. Estimation of age at death using cortical histomorphometry of the sternal end of the fourth rib. Journal of Forensic Science. 1994 May 1;39(3):778-84.

DOI: https://doi.org/10.1520/JFS13655]

15. Oettle AC, Steyn M. Age estimation from sternal ends of ribs by phase analysis in South African blacks. J Forensic Sci. 2000 Sep 1;45(5):1071-9.

DOI: https://doi.org/10.1520/JFS14831J

16. Keough N. Estimation of age at death from the microscopic structure of the femur (Doctoral dissertation, University of Pretoria). 2007.

17. Crowder C, Dominguez VM. Estimation of age at death using cortical bone histomorphometry. US
Department of Justice, National Institute of Justice. 2013 Jan. 2013.

18. Kerley ER. The microscopic determination of age in human bone. American journal of physical anthropology. 1965 Jun;23(2):149-63.

DOI: https://doi.org/10.1002/ajpa.1330230215

19. Kerley ER. Age determination of bone fragments. Journal of Forensic Sciences. 1969 Jan 1;14(1):59-67.

20. Uytterschaut HT. Determination of skeletal age by histological methods. Zeitschrift für Morphologie und Anthropologie. 1985 Jun 1:331-40.

21. Ruddle JL. An investigation of bone histology as a potential age indicator in roe deer (Doctoral dissertation, University of London). 1997.

22. Singh IJ, Gunberg DL. Estimation of age at death in human males from quantitative histology of bone fragments. American Journal of Physical Anthropology. 1970 Nov;33(3):373-81.

DOI: https://doi.org/10.1002/ajpa.1330330311

23. Stout SD, Dietze WH, Işcan MY, Loth SR. Estimation of age at death using cortical histomorphometry of the sternal end of the fourth rib. Journal of Forensic Science. 1994 May 1;39(3):778-84.

DOI: https://doi.org/10.1520/JFS13655]

24. Maat GJR, Aarents MJ and Nagelkerke NJD. Age prediction from bone replacement: Remodeling of circumferential lamellar bone tissue in the anterior cortex of the femoral shaft of the present Dutch population. Barge's Anthropologica Leiden, Leiden University Medical Centre. 2003;10:1-19.

25. Meltem $\mathrm{K}$ and Dincer A. Age determination and long bone histology inStellagamastellio(Linnaeus, 1758) (Squamata: Sauria:Agamidae) populations in Turkey, SenckenbergGesellschaft fur Naturforschung. 2014;64(1):113-26.

26. De Boer $\mathrm{HH}$ and Maat GJR. The histology of human dry bone: A review. Barge's Anthropologica CPAG. 2003;22:49-65.

27. Thomas CD, Stein MS, Feik SA, Wark JD, Clement JG. Determination of age at death using combined morphology and histology of the femur. Journal of Anatomy. 2000 Apr;196(3):463-71.

DOi: https://doi.org/10.1046/j.1469-7580. 2000.19630463.x

28. Wolf M, Streit B, Dokladal M, et al. Determining human age at death using cremated bone microctructure. Biomed J Sci\& Tech Res. 2017;1(3):785-91.

DOI: https://doi.org/10.26717/BJSTR.2017. 01.000304

29. Stout SD. Methods of determining age at death using bone microstructure. In: Sanders SR, Katzenberg MA (eds). Skeletal Biology of past peoples: Research Methods, Wiley-Liss. 1992. p. 21-5.

30. Ingraham MR. Histological age estimation of the midshaft clavicle using a new digital technique. M.Sc Thesis (Biology), University of North Texas, 2004.

31. Nor FM, Pastor RF, Schutkowski H. Age at death estimation from bone histology in Malaysian males. Medicine, Science and the Law. 2014 Oct; 54(4):203-8. 
32. Ericksen MF. Histologic estimation of age at death using the anterior cortex of the femur. American J Physical Anthro. 1991; 84:171-79.

DOI: https://doi.org/10.1002/ajpa.1330840207

33. Steyn M, Loots M and L'Abbe EN. Adult age estimation. Forensic Anthropology, Department of Anatomy, University of Pretoria, 2004.

34. Aiello $L$ and Molleson T. Are microscopic ageing techniques more accurate than macroscopic ageing techniques? J Archaeological Sci. 1993; 20:689-704

DOI: https://doi.org/10.1006/jasc.1993.1043

35. Frost HM. Preparation of thin undecalcified bone sections by rapid manual method. Stain Technology. 1958;33:271-76.

DOI: https://doi.org/10.3109/10520295809111862

36. Maat GJR, Robert PMV and Aarents MJ. Manual Preparation of Ground Sections for the Microscopy of Natural Bone Tissue: Update and Modification of Frost's Rapid Manual Method. Int. J. Osteoarchaeol 2001;11:366-74.

DOI: https://doi.org/10.1002/oa.578

37. Landeros $\mathrm{O}$ and Frost HM. Radial rate of osteon closure measured by means of tetra-cycline labelling. Henry Ford Hosp. Med. Bull. 1964;12:499505.

38. Barer M and Jowsey J. Bone formation and resorption in normal human rib. A study of persons from 11 to 88 years of age. Clin.Orthopaedics 1967; 52:241-47

DOI: https://doi.org/10.1097/00003086196700520-00020

39. Enlow DH. The canal system in bone. In:
XXXXX (Ed), Principles of Bone Remodeling. CC Thomas, Springfield, 1963; pp. 60-74.

40. Tersigni MA. Serial Long Bone Histology: Inter- and Intra-Bone Age Estimation. PhD diss., University of Tennessee, 2005.

41. Purves S, Woodley L and Hackman L. Age determination in the Adult. In: Black S, Ferguson E (eds). Forensic Anthropology 2000-2010. 2011; Pp 29-60.

DOI: https://doi.org/10.1201/b10727-3

42. United Nations Development Programme/ Oxford Poverty \& Human Development Initiative. 2019 global multidimensional poverty index. www. ng.undp.org/content/Nigeria/en/home/presscenter/pressrelease/2019/new-data-challenges (2019, accessed 12 December 2019)

43. Thompson DD and Gunness-Hey M. Bone mineral-osteon analysis of Yupik-Inupiaq Skeletons. American J Physical Anthro.1981; vol. 55, pp. 1-7.

DOI: https://doi.org/10.1002/ajpa.1330550102

44. Abdullah $\mathrm{H}$, Jamil MMA, Ambar R, et al. Bone histology: A key for human sex determination after death. J. Phys.: Conf. Ser. 2018; 1019: 012010.

DOI: https://doi.org/10.1088/1742-6596/1019/ $1 / 012010$

Received 30 Sep 2020; revised 25 Nov 2020; accepted 3 Dec 2020.

This is open access article distributed under the Creative Commons Attribution License, which permits unrestricted use, distribution, and reproduction in any medium, provided the original work is properly cited. 